\title{
Suppression of molten salt corrosion by plasma sprayed $\mathrm{Ni}_{3} \mathrm{Al}$ coatings
}

\author{
Sarah Yasir $^{1}$ · Jose Luis Endrino ${ }^{1,2,3} \cdot$ Elena Guillén ${ }^{4} \cdot$ Adrianus Indrat Aria ${ }^{1}$ (])
}

Received: 23 June 2021 / Accepted: 9 December 2021 / Published online: 23 December 2021

(c) The Author(s) 2021

\begin{abstract}
Corrosion behaviour of stainless steel 347 was investigated in a molten nitrate salt $\left(60 \mathrm{wt} \% \mathrm{NaNO}_{3}+40 \mathrm{wt} \% \mathrm{KNO}_{3}\right)$ immersion at $565{ }^{\circ} \mathrm{C}$ for up to $3000 \mathrm{~h}$. A growth of stratified oxide layers consisting of $\mathrm{NaFeO}_{2}, \mathrm{Fe}_{2} \mathrm{O}_{3}$ and $\mathrm{Fe}_{3} \mathrm{O}_{4}$ was observed on the stainless steel surface with a constant gravimetric corrosion rate of $\sim 0.4 \mu \mathrm{m} / \mathrm{year}$. The feasibility of using $\mathrm{Ni}_{3} \mathrm{Al}$ coatings deposited by means of air plasma spray for suppression of corrosion was investigated. $\mathrm{Ni}_{3} \mathrm{Al}$ coatings were observed to undergo a fast oxidation with a corrosion rate of $\sim 2.7 \mu \mathrm{m} /$ year in the first $500 \mathrm{~h}$, and subsequently stabilise between 500 and $3000 \mathrm{~h}$ with no observable changes in microstructure, composition and weight at a corrosion rate of $\sim 0.02 \mu \mathrm{m} / \mathrm{year}$. The results presented in this study strongly suggest that $\mathrm{Ni}_{3} \mathrm{Al}$ coating suppresses the formation of oxide layers on the surface of stainless steel substrates and can be used as protection against corrosion in the presence of molten nitrate salts, which is of relevance to thermal energy storage applications.
\end{abstract}

Keywords Molten nitrate salts $\cdot$ Stainless steel corrosion $\cdot \mathrm{Ni}_{3} \mathrm{Al}$ coatings $\cdot$ Air plasma spray $\cdot$ Corrosion resistant coatings

\begin{tabular}{ll}
\multicolumn{2}{l}{ Abbreviations } \\
TES & Thermal energy storage \\
LCOE & Levelised cost of energy \\
CSP & Concentrated solar power \\
SS & Stainless steel \\
IPA & Isopropyl alcohol \\
APS & Air plasma spray \\
SEM & Scanning electron microscope \\
EDS & Energy-dispersive X-ray spectroscopy \\
XRD & X-ray diffraction \\
$\mathrm{R}_{\mathrm{a}}$ & Arithmetic average surface roughness
\end{tabular}

Adrianus Indrat Aria

A.I.Aria@cranfield.ac.uk

1 Surface Engineering and Precision Centre, Cranfield University, College Road, Cranfield MK43 0AL, Bedfordshire, UK

2 Nano4Energy, Calle de José Gutiérrez Abascal, 2, 28006 Madrid, Spain

3 Universidad Loyola Andalucia, Av de las Universidades s/n, 41704 Dos Hermanas, Seville, Spain

4 Profactor GmbH, Im Stadtgut A2, 4407, Steyr-Gleink, Steyr, Austria

\section{Introduction}

Thermal energy storage (TES) is arguably the key to further lower the levelised cost of energy (LCOE) of concentrated solar power (CSP) into a comparable level with other electricity generation technologies [1-6]. TES allows continuous power generation beyond sunset and over periods of overcast [7]. A feasible storage medium for TES is molten salt with high temperature stability, low melting point, low viscosity and high thermal conductivity [8-10]. Binary nitrate eutectic salts such as $60 \% \mathrm{NaNO}_{3}-40 \% \mathrm{KNO}_{3}$ are commonly used as heat storage media because of their high heat capacity of $\sim 1495 \mathrm{~J} \mathrm{~kg}^{-} 1 \mathrm{~K}^{-1}$ at $300{ }^{\circ} \mathrm{C}$, high thermal conductivity of $0.55 \mathrm{~W} \mathrm{~m} \mathrm{~m}^{-} 1 \mathrm{~K}^{-1}$ at $400{ }^{\circ} \mathrm{C}$ and ease of handling and storage [11-14]. One of the challenges associated with molten salts is corrosion at elevated temperatures [15-21]. The commonly used solution to accommodate corrosion is to use thicker walls, as it would extend the lifetime operation of the material. However, it does not solve the corrosion issue and may not be applicable for components with fixed dimensions or tight tolerance [22]. The use of high purity nitrate salt to avoid corrosion aggravation from chloride and water impurities has been proposed, although not widely implemented due to higher costs [7, 22, 23]. Ni-based superalloys have also been proposed to suppress corrosion, as they provide high temperature stability and resistance for molten salt corrosion compared to iron-based alloys [22, 24, 25]. However, 
they are significantly more expensive as compared to structural stainless steel $[24,25]$. The use of corrosion resistant coatings has been considered as the most viable solution, as it provides barrier to suppress corrosion while maintaining the structural stability of substrate material [25-28].

Due to a large variation in operational temperature, it is best practice to match the thermal properties of the coating with substrate material to minimize cracking or spallation with temperature change [29]. For stainless steel substrate, commonly used in TES, the most suitable coating material would ideally be Fe-based, Cr-based or Ni-based. Cr-based material forms a slow growing protective $\mathrm{CrO}_{\mathrm{x}}$ under an oxidising environment. However, it is unsuitable for use in molten nitrate salts due to its high solubility $[15,17,19$, 25, 29-32]. Ni-based coating is preferred over Fe-based because of its ability to form a protective oxide layer, whilst $\mathrm{Fe}$ oxide is non-passivating [21]. Ni-based coatings have been reportedly used to provide wear, oxidation and hot corrosion resistance in ash and flue gases inside a coal-fire boiler [33, 34]. Among many potential different combinations of Ni-based coatings, $\mathrm{NiAl}_{\mathrm{x}}$ are favoured because of their strong adhesion, high-temperature mechanical strength, high melting temperature, high thermal conductivity, attractive stiffness, good oxidation resistance and metal-like electrical conductivity $[35,36] . \mathrm{Ni}_{2} \mathrm{Al}_{3}$ coatings showed very low mass changes after 1000-h immersion in molten $60 \%$ $\mathrm{NaNO}_{3}-40 \% \mathrm{KNO}_{3}$ salt at $580{ }^{\circ} \mathrm{C}$ [25]. NiVAl has been reported to have a corrosion rate of $0.11 \mathrm{~nm} / \mathrm{h}$ after $2000-\mathrm{h}$ immersion in $60 \% \mathrm{NaNO}_{3}-40 \% \mathrm{KNO}_{3}$ salt at $500{ }^{\circ} \mathrm{C}$, which is more than two orders of magnitude lower than uncoated high temperature Grade P91 9Cr-1Mo steel [22]. Compared to the aforementioned different phases of $\mathrm{NiAl}_{\mathrm{x}}, \mathrm{Ni}_{3} \mathrm{Al}$ is more favourable because of lower concentration of $\mathrm{Al}$ to avoid brittleness after oxidation. $\mathrm{Ni}_{3} \mathrm{Al}$ coating was effective in decreasing the weight gain to about one-third as compared to uncoated $\mathrm{Fe}$-based superalloy in molten $\mathrm{Na}_{2} \mathrm{SO}_{4}-60 \%$ $\mathrm{V}_{2} \mathrm{O}_{5}$ salt at $900{ }^{\circ} \mathrm{C}$ [28]. The $\mathrm{Ni}_{3} \mathrm{Al}$ coating have been effectively used in a coal-fired boiler at $450{ }^{\circ} \mathrm{C}$ and $900{ }^{\circ} \mathrm{C}$, as well as in molten $\mathrm{NaNO}_{3}-\left(\mathrm{KNO}_{3}\right)-\mathrm{Na}_{2} \mathrm{O}_{2}$ salt at $650{ }^{\circ} \mathrm{C}$ $[15,37,38]$. Numerous studies on $\mathrm{Ni}_{3} \mathrm{Al}$ coatings and their corrosion resistance in different high-temperature atmospheres have been reported in the literature. However, the long-term corrosion behaviour of $\mathrm{Ni}_{3} \mathrm{Al}$ coatings in molten binary nitrate salt at $565{ }^{\circ} \mathrm{C}$, emulating a realistic CSP-TES environment, has not been systematically investigated $[1,5$, $12,13,39]$.

The study presented herein investigates high temperature behaviour of $\mathrm{Ni}_{3} \mathrm{Al}$ coatings immersed in molten $60 \% \mathrm{NaNO}_{3}-40 \% \mathrm{KNO}_{3}$ salt to address the challenge of hot corrosion on stainless steel substrates typically used in CSP-TES application. The results of this investigation show that $\mathrm{Ni}_{3} \mathrm{Al}$ yields a practically negligible change in microstructures, elemental composition and corrosion rate at a constant temperature of $565^{\circ} \mathrm{C}$ for up to $3000 \mathrm{~h}$. This suggests $\mathrm{Ni}_{3} \mathrm{Al}$ coatings may be highly suitable for use as protective coatings in applications with long term isothermal exposure to molten salt, such as the hot TES tanks and piping systems. Furthermore, this study provides a more suitable approach to approximate corrosion behaviour which should be adapted in other studies and applied to future coating systems.

\section{Materials and methods}

High temperature stainless steel AISI 347 circular coupons with a dimension of $10-\mathrm{mm}$ diameter and 2-mm thickness (Goodfellow, temper annealed) were used as substrates. All coupons were cleaned in an ultrasonic bath of isopropyl alcohol (IPA) for $10 \mathrm{~min}$ at $25{ }^{\circ} \mathrm{C}$ to remove oil and dirt before coating or testing. Some of the SS347 coupons were left uncoated and denoted herein as SS347. The remaining set of coupons were coated with $\sim 200-\mu \mathrm{m}$ thick $\mathrm{Ni}_{3} \mathrm{Al}$ layer on all sides of the substrate, denoted herein as $\mathrm{Ni}_{3} \mathrm{Al} / \mathrm{SS} 347$, using air plasma spray (Fig. 1a). Prior to the coating deposition, the substrates were grit blasted with 80 grit alumina powders to clean and roughen. The $\mathrm{Ni}_{3} \mathrm{Al}$ coatings were introduced by an air plasma spray (APS) system with a current setting of $500 \mathrm{~A}$ and a voltage of $35 \mathrm{~V}$ (Multicoat system, 9MPE-CL feeder and $9 \mathrm{M}$ spray gun). $\mathrm{N}_{2}$ gas at $5600 \mathrm{sccm}$ was used as carrier gas to deliver $\mathrm{Ni}_{3} \mathrm{Al}$ powder (Goodfellow NI716010, 20-45- $\mu \mathrm{m}$ particle size) at a feed rate of $67 \pm 5 \mathrm{~g} / \mathrm{min}$ (see Supporting Information Fig. S1). Ar and $\mathrm{H}_{2}$ gases were used as the primary and secondary plasma gases with a flow rate of 36,700 and $7000 \mathrm{sccm}$, respectively. The powders were characterised by scanning electron microscopy (SEM) and energy-dispersive X-ray spectroscopy (EDS) prior to APS deposition to confirm particle size distribution and elemental composition (see Supporting Information Table S1). The coatings were deposited at a spray distance of $150 \mathrm{~mm}$. All corrosion behaviour assessments were carried out by immersion in eutectic solar nitrate salt mixture consisting of 60 wt $\% \mathrm{NaNO}_{3}$ (Sigma-Aldrich, BioXtra, $\geq 99.0 \%$ ) and $40 \mathrm{wt} \%$ $\mathrm{KNO}_{3}$ (Sigma-Aldrich, BioXtra, $\geq 99.0 \%$ ) at a constant temperature of $565^{\circ} \mathrm{C}$ for up to $3000 \mathrm{~h}$ unless otherwise stated. Both salts were mixed for 20 min in a ball mill (Fritsch Pulverisette 5) until a homogeneous mixture was obtained and then filled into alumina crucibles (volume of $\sim 10 \mathrm{ml}$ ). Prior to use in the corrosion test, the mixture was fully melted by heating at $400{ }^{\circ} \mathrm{C}$ for $24 \mathrm{~h}$. Each of the SS347 and $\mathrm{Ni}_{3} \mathrm{Al} /$ SS347 samples was individually immersed in a separate crucible to avoid cross corrosion and contamination. The crucibles, each containing a single piece of the test sample, were placed back in the furnace purged and filled with $\mathrm{Ar}$ gas to prevent gaseous phase oxidation from $\mathrm{O}_{2}$ or moisture in the air (Fig. 1a). The furnace temperature was then slowly 
Fig. 1 (a) Schematics of air plasma spray deposition of $\mathrm{Ni}_{3} \mathrm{Al}$ coatings and molten nitrate salt tests at $565^{\circ} \mathrm{C}$. $\mathrm{Ni}_{3} \mathrm{Al}$ powder is melted in a stream of plasma at atmospheric pressure and propelled towards the substrate. Each of the SS347 and $\mathrm{Ni}_{3} \mathrm{Al} / \mathrm{SS} 347$ coupons is then immersed in $\mathrm{NaNO}_{3}: \mathrm{KNO}_{3}$ salts contained in individual alumina crucibles at a constant temperature of $565{ }^{\circ} \mathrm{C}$ for up to $3000 \mathrm{~h}$. (b) Time dependent area-normalised weight change $(\Delta \mathrm{M} / \mathrm{A})$ of $\mathrm{Ni}_{3} \mathrm{Al} / \mathrm{SS} 347$ and SS347 in molten nitrate salts and air at $565^{\circ} \mathrm{C}$. Here, the weight change is normalised with the surface area of the coupons. Solid and dashed lines indicate piecewise linear regressions for weight change in molten nitrate salts and air, respectively.
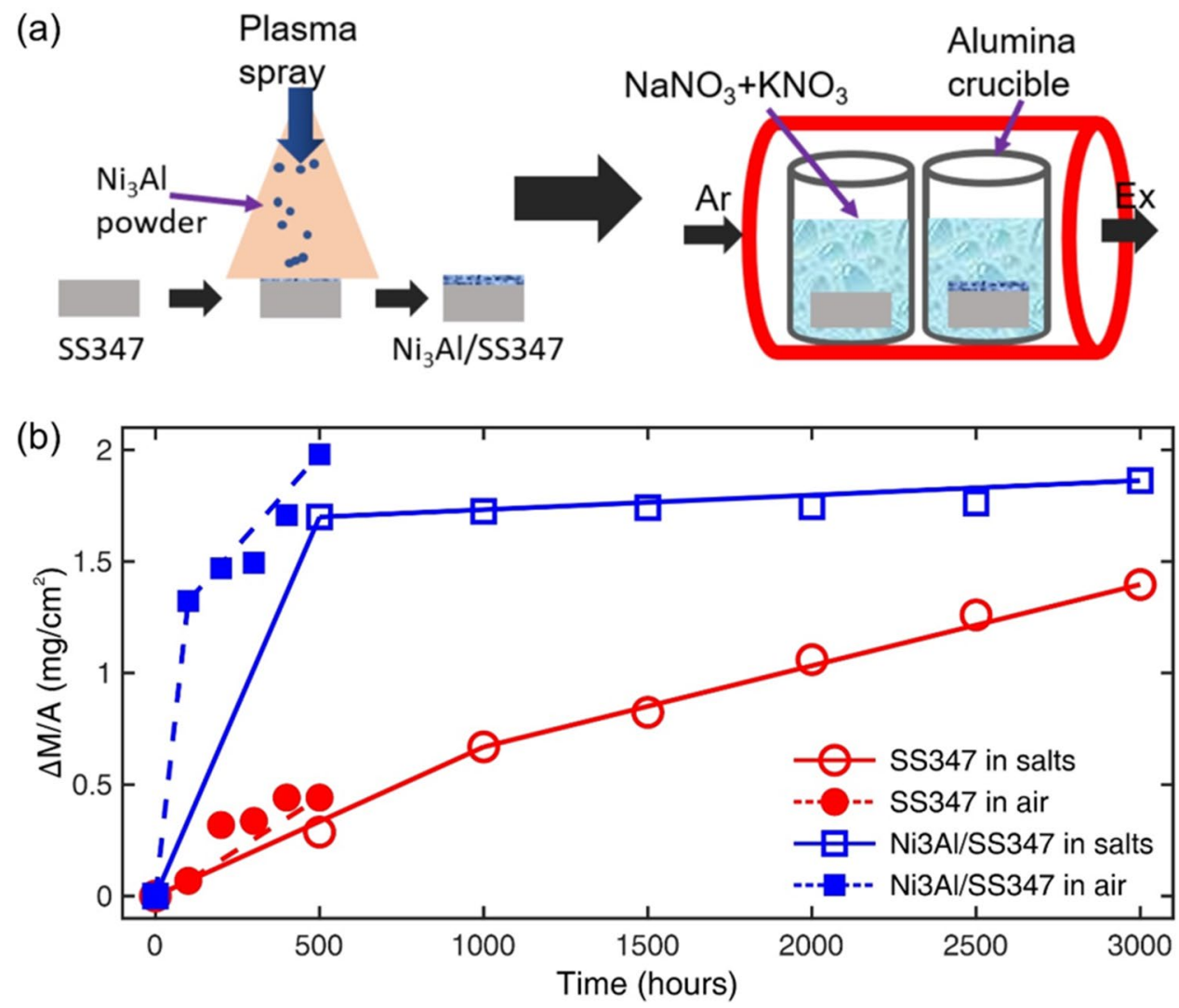

raised to $565{ }^{\circ} \mathrm{C}$ and maintained throughout the duration of the corrosion tests. The samples were removed from the furnace after every 500-h interval to be weighed (Sartorius CP225D balance; 0.01-mg resolution) and characterised. After removal from the furnace, each sample was thoroughly cleaned in an ultrasonic bath of deionised water for $10 \mathrm{~min}$ at $25^{\circ} \mathrm{C}$ to remove any salt residues from the surface.

Scanning electron microscopy (SEM) images of sample surfaces and cross-sections were collected by secondary electron detectors (TESCAN VEGA3) under the acceleration voltage of $20 \mathrm{kV}$. Material characterisation was carried out by means of energy-dispersive X-ray spectroscopy (EDS) for elemental analysis collected by a $20-\mathrm{mm}^{2}$ silicon drift detector (Oxford Instrument X-max with AZtec software) under acceleration voltage of $20 \mathrm{kV}$ along with $\mathrm{X}$-ray diffraction (XRD) for crystallography analysis (Siemens D5005 X-ray diffractometre with DIFFRACT plus software) collected under $\mathrm{Cu} \mathrm{K} \alpha$ radiation at power setting of $40 \mathrm{kV}$ and $40 \mathrm{~mA}$. Cross-sectioning was carried out by mounting samples in Bakelite resin at $185^{\circ} \mathrm{C}$, grinding using sandpaper with a gradual increase from 120 to 2500 grit paper, polishing using diamond coarse polish (Met-prep, Durasilk 3- $\mu \mathrm{m}$ diamond suspension) and silica final polish (Struers, OP-S 0.04- $\mu$ m colloidal silica suspension), rinsing with detergent and tap water to remove residual substances from the metallographic process, and drying with a hot air blow dryer. The arithmetic average surface roughness $\left(\mathrm{R}_{\mathrm{a}}\right)$ was measured by a stylus profilometre (Bruker DektakXT).

\subsection{Results and discussion}

The overall corrosion behaviour of any metallic samples is typically assessed by gravimetric analysis in a form of mass changes per unit surface area $(\Delta \mathrm{M} / \mathrm{A})[40]$. The $\Delta \mathrm{M} / \mathrm{A}$ of $\mathrm{Ni}_{3} \mathrm{Al} / \mathrm{SS} 347$ at $565{ }^{\circ} \mathrm{C}$ is observed to increase rapidly within the first $500 \mathrm{~h}$ to $\sim 1.05 \times 10^{-1} \mathrm{mg} / \mathrm{cm}^{2}$ at an apparent rate of $\sim 2 \times 10^{-4} \mathrm{mg} / \mathrm{cm}^{2} / \mathrm{h}$ (Fig. 1b). After 500-h immersion in molten salts, $\Delta \mathrm{M} / \mathrm{A}$ of $\mathrm{Ni}_{3} \mathrm{Al} / \mathrm{SS} 347$ stabilises at a much lower rate of $\sim 1.8 \times 10^{-6} \mathrm{mg} / \mathrm{cm}^{2} / \mathrm{h}$. This results in $\Delta \mathrm{M} / \mathrm{A}$ of just $\sim 1.1 \times 10^{-1} \mathrm{mg} / \mathrm{cm}^{2}$ after $3000 \mathrm{~h}$. Assuming the $\mathrm{Ni}_{3} \mathrm{Al}$ coatings remain at a constant density of $6.67 \times 10^{3} \mathrm{mg} / \mathrm{cm}^{3}$, this is equivalent to an effective corrosion rate of $\sim 2.7 \mu \mathrm{m} /$ year within the first $500 \mathrm{~h}$ and a practically negligible rate of $\sim 0.02 \mu \mathrm{m} /$ year from 500 to $3000 \mathrm{~h}$. In contrast, $\Delta \mathrm{M} / \mathrm{A}$ of SS347 increases monotonically with increasing molten salt immersion time at a rate of $\sim 4.7 \times 10^{-5} \mathrm{mg} / \mathrm{cm}^{2} / \mathrm{h}$ within the first $1000 \mathrm{~h}$, and subsequently at a rate of $\sim 3 \times 10^{-5} \mathrm{mg} /$ $\mathrm{cm}^{2} / \mathrm{h}$ to reach an $\Delta \mathrm{M} / \mathrm{A}$ of $\sim 1.07 \times 10^{-1} \mathrm{mg} / \mathrm{cm}^{2}$ after $3000 \mathrm{~h}$ (Fig. 1b). Assuming the SS347 substrates remain at a constant density of $8.03 \times 10^{3} \mathrm{mg} / \mathrm{cm}^{3}$, this is equivalent to an overall corrosion rate of $\sim 0.4 \mu \mathrm{m} /$ year in molten salts. This corrosion rate is in agreement with previous studies, 
where that for SS347 at $500-600{ }^{\circ} \mathrm{C}$ prior to descaling was observed between 0.1 and $2.2 \mu \mathrm{m} /$ year (see Supporting Information Table S2) [21, 41].

We postulate that such a rapid increase in $\Delta \mathrm{M} / \mathrm{A}$ of $\mathrm{Ni}_{3} \mathrm{Al} / \mathrm{SS} 347$ within the first $500 \mathrm{~h}$ is attributed to rapid oxidation of $\mathrm{Al}$ and $\mathrm{Ni}$ in the $\mathrm{Ni}_{3} \mathrm{Al}$ coatings without necessarily involving any uptake of Na. Note that the decomposition of nitrate salt into $\mathrm{NO}$ and $\mathrm{O}_{2}$ gasses in the presence of Ar atmosphere, which was used to purge and fill the test furnace, starts at a temperature of $\sim 470{ }^{\circ} \mathrm{C}$ [10]. At a temperature of $565^{\circ} \mathrm{C}$, the concentration of $\mathrm{O}_{2}$ from partial decomposition of molten salt is sufficiently high to facilitate rapid uptake of $\mathrm{O}$ through oxidation. To verify this postulation, we carried out molten salt-free heat treatment tests in air at $565{ }^{\circ} \mathrm{C}$ for $500 \mathrm{~h}$. In agreement with the test in molten salt, heat treatment in air confirms substantial increase in $\Delta \mathrm{M} / \mathrm{A}$ of $\mathrm{Ni}_{3} \mathrm{Al} / \mathrm{SS} 347$ due to a rapid uptake of $\mathrm{O}[42]$. As $\mathrm{Ni}_{3} \mathrm{Al}$ coatings act as an $\mathrm{O}$ sink, $\Delta \mathrm{M} / \mathrm{A}$ of $1.2 \times 10^{-1} \mathrm{mg} / \mathrm{cm}^{2}$ is quickly reached within the first $500 \mathrm{~h}$ (Fig. 1b). A similar behaviour is also observed on SS347, where the increase rate in $\Delta \mathrm{M} / \mathrm{A}$ from heat treatment in air is comparable to that from immersion in molten nitrate salts within the first $500 \mathrm{~h}$. This observation suggests that rapid increase in $\Delta \mathrm{M} / \mathrm{A}$ can be attributed mainly to the uptake of $\mathrm{O}$ through oxidation. The negligible increase in $\Delta \mathrm{M} / \mathrm{A}$ of $\mathrm{Ni}_{3} \mathrm{Al} / \mathrm{SS} 347$ after $500 \mathrm{~h}$ in molten salts suggests an abrupt slowdown of $\mathrm{O}$ uptake once the majority of $\mathrm{Ni}$ and $\mathrm{Al}$ in the $\mathrm{Ni}_{3} \mathrm{Al}$ coating has been oxidised. In contrast, a further increase in $\triangle \mathrm{M} / \mathrm{A}$ of SS347 beyond $500 \mathrm{~h}$ suggests the oxidation process takes place continuously and has not stopped even at $3000 \mathrm{~h}$.
It is important to note that the approximation of corrosion rate based on $\Delta \mathrm{M} / \mathrm{A}$ needs to be carried out in a piecewise manner due to the abrupt slowdown of the $\mathrm{O}$ uptake at $500 \mathrm{~h}$ in molten salts. Such an approximation should not be based solely on the final $\Delta \mathrm{M} / \mathrm{A}$ value measured at the maximum test time, as is typically reported in literature [31]. Both distinctive trends need to be considered to fully capture the critical information on time dependent corrosion behaviour. As an illustration, the corrosion rate of $\mathrm{Ni}_{3} \mathrm{Al} / \mathrm{SS} 347$ would have been mistakenly reported as $\sim 0.5 \mu \mathrm{m} /$ year had it been calculated solely based on the final $\Delta \mathrm{M} / \mathrm{A}$ value measured at $3000 \mathrm{~h}$. This is incorrect for both regimes as it does not capture the change in the $\mathrm{O}$ uptake that occurs at $500 \mathrm{~h}$. Furthermore, there is currently no consensus in literature whether pre-descaling is required [21, $25,30,31,43]$ or not $[15,22,28,34,37,38]$ in the measurement of $\Delta \mathrm{M} / \mathrm{A}$. Descaling is not performed in this study to capture the full evolution of the oxide layers without damaging the substrate.

Cross-sectional SEM images of $\mathrm{Ni}_{3} \mathrm{Al} / \mathrm{SS} 347$ suggest that the immersion in molten nitrate salts at $565{ }^{\circ} \mathrm{C}$ induces minimal changes to the microstructural morphologies of $\mathrm{Ni}_{3} \mathrm{Al}$ coatings and $\mathrm{SS} 347$ substrates. $\mathrm{Ni}_{3} \mathrm{Al} / \mathrm{SS} 347$ at $0 \mathrm{~h}$ exhibits lamellar coating morphology with numerous unmelted $\mathrm{AlO}_{\mathrm{x}}$ particles and air cavities, which is typical for metal alloy coatings deposited by APS with high powder feed rate (Fig. 2a). APS allows direct deposition of $\mathrm{Ni}_{3} \mathrm{Al}$ coatings on SS347 substrates with good contact and without the need of bond coat. The cross-sectional SEM image of $\mathrm{Ni}_{3} \mathrm{Al} / \mathrm{SS} 347$ at $3000 \mathrm{~h}$ appears similar to that of the as deposited one, albeit with less cavities within the lamellar
Fig. 2 Cross-sectional SEM images of Ni3Al/SS347 (a, b) and SS347 (c, d) at $0 \mathrm{~h}(\mathrm{a}, \mathrm{c})$ and $3000 \mathrm{~h}(\mathrm{~b}, \mathrm{~d})$ of immersion in molten nitrate salt at $565{ }^{\circ} \mathrm{C}$. Dashed lines indicate the interface between Ni3Al coating and SS347 substrate, while arrows indicate $\mathrm{AlOx}$ particles embedded within the Ni3Al coatings $(a, b)$. No significant change in the coating morphology and no formation of corrosion layers can be observed on Ni3Al/ SS347 after 3000 h. In contrast, formation of corrosion layers can be observed on the surface SS347 after $3000 \mathrm{~h}$. A higher magnification SEM image (inset in d) shows the distinguishable morphologies of these corrosion layers. The dashed line in the inset indicates the interface between the corrosion layers and the original SS347 layer
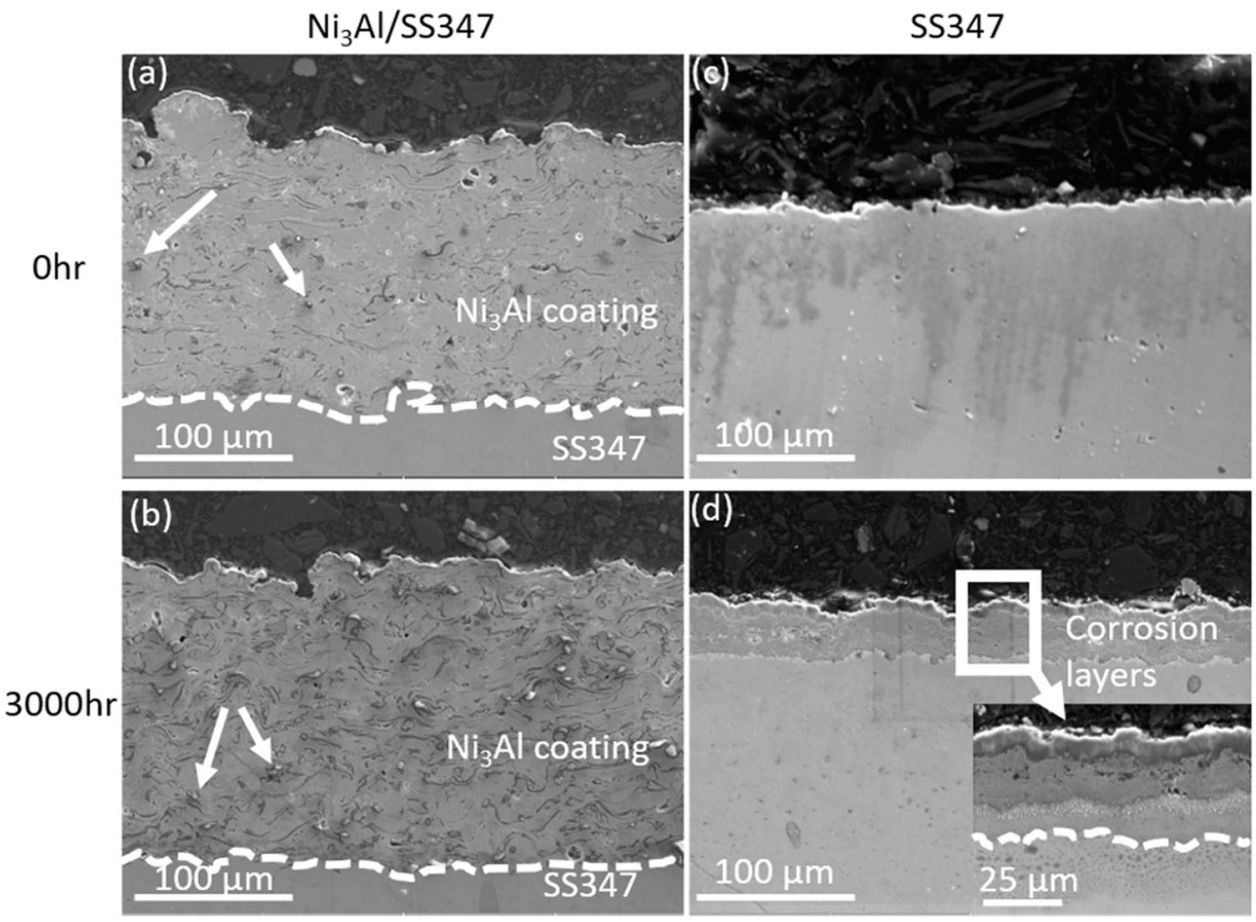
structures due to amalgamation of some lamellae into more continuous structures at an elevated temperature (Fig. 2b). The surface SEM image of the $\mathrm{Ni}_{3} \mathrm{Al} / \mathrm{SS} 347$ at $300 \mathrm{~h}$ exhibits surface features of $\sim 1 \mu \mathrm{m}$ (average size), in addition to the splats with lateral average size of $\sim 5 \mu \mathrm{m}$ in the surface SEM image of the $\mathrm{Ni}_{3} \mathrm{Al} / \mathrm{SS} 347$, prior to molten salt immersion $(0 \mathrm{~h})$ (see Supporting Information Fig. S2a, b). The $\mathrm{Ni}_{3} \mathrm{Al}$ coatings exhibit no visible degradation, and no formation of corrosion product layers can be observed in the underlying SS347 substrate. This strongly suggests the potential longterm corrosion protective nature of $\mathrm{Ni}_{3} \mathrm{Al}$ coatings [25].

In contrast, the immersion in molten salt leads to dramatic changes in microstructural morphologies near the surface of bare SS347. Corrosion product layers, which are non-existent on SS347 at $0 \mathrm{~h}$ (Fig. 2c), start to form on the surface immediately upon exposure to molten salt at $565^{\circ} \mathrm{C}$. Both the thickness and the number of distinguishable layers can be observed to grow with the increase in molten salt immersion time. SEM images of SS347 at $3000 \mathrm{~h}$ show at least four distinguishable corrosion layers with a total thickness of $40-50 \mu \mathrm{m}$ (Fig. 2d). The observed stratification suggests each layer comprises different elemental compositions or crystalline structures. The two outermost corrosion layers exhibit distinctive porous columnar structures with numerous sub-surface microscale cavities. The morphologies of these layers closely resemble the outer and inner layers of $\mathrm{FeO}_{\mathrm{x}}$ scales formed naturally on steel alloys under strongly oxidising environment at elevated temperatures [44-47]. The corrosion layers closer to original SS347 surface appear more compact with numerous precipitates and multiphase microstructures. These layers resemble diffusion layers at which the oxide formation terminates [44-47]. The SEM image of the SS347 exhibits a typical smooth stainless steel surface with an average grain size of $\sim 4 \mu \mathrm{m}$, prior to molten salt immersion (0 h) (see Supporting Information Fig. S2c). Changes in surface morphology of the SS347 could be observed after $3000 \mathrm{~h}$, where the average size of the apparent surface features decreases to $\sim 1 \mu \mathrm{m}$ (see Supporting Information Fig. S2d). The decrease in the surface feature size is not caused by the shrinkage of the alloy grains, but rather by the formation of fine corrosion product adlayer that resembles $\mathrm{FeO}_{\mathrm{x}}$ scales on the surface of the SS347.

The rapid increase in $\triangle \mathrm{M} / \mathrm{A}$ of $\mathrm{Ni}_{3} \mathrm{Al} / \mathrm{SS} 347$ along with its absence of corrosion layers motivate us to carry out elemental composition analysis, particularly around the interface between Ni3Al coatings and SS347 substrates (Fig. 3a). The spatial distribution of $\mathrm{O}$ obtained from qualitative crosssectional EDS maps confirms its presence in the $\mathrm{Ni}_{3} \mathrm{Al}$ coatings and its absence in the SS347 substrates. This strongly suggests that the rapid increase in $\Delta \mathrm{M} / \mathrm{A}$ is indeed caused by rapid uptake of $\mathrm{O}$ through formation of $\mathrm{AlO}_{\mathrm{x}}$ and $\mathrm{NiO}_{\mathrm{x}}$ in the $\mathrm{Ni}_{3} \mathrm{Al}$ coatings instead of the formation of $\mathrm{FeO}_{\mathrm{x}}$ in the SS347 substrates [37, 38, 48, 49]. Note that the spatial correlation between $\mathrm{O}$ and $\mathrm{Al}$ is more pronounced than that between $\mathrm{O}$ and $\mathrm{Ni}$ throughout the coatings. This suggests $\mathrm{AlO}_{\mathrm{x}}$ is more readily formed than $\mathrm{NiO}_{\mathrm{x}}$ upon exposure to molten nitrate salts. As mentioned earlier, un-melted $\mathrm{AlO}_{\mathrm{x}}$ particles with size of tens of $\mu \mathrm{m}$ may also be inadvertently introduced during the APS deposition (indicated by arrows in Fig. 2a, b and 3a). A much lower powder feed rate is needed to minimise the quantity of these un-melted $\mathrm{AlO}_{\mathrm{x}}$ particles. Nonetheless, the oxidation of $\mathrm{Ni}_{3} \mathrm{Al}$ coatings may contribute to the suppression of inward/outward diffusion of other elements, such as $\mathrm{Na}$ and $\mathrm{Fe}$, from/to the surrounding molten salt environment.

A quantitative elemental composition analysis across the thickness of the $\mathrm{Ni}_{3} \mathrm{Al}$ coatings at $3000 \mathrm{~h}$ further confirms the suppression of inward and outward diffusions of $\mathrm{Na}$ and $\mathrm{Fe}$, respectively (Fig. 3b). Na is practically non-existent in both $\mathrm{Ni}_{3} \mathrm{Al}$ coatings and SS347 substrate as its concentration is indistinguishable from the noise level. The coatingsubstrate interdiffusion zone, in which the concentration of $\mathrm{Al}$ and Ni rapidly increases to about $\sim 18$ at. $\%$ and $~ 60$ at.\%, respectively, is found to be about $7-8-\mu \mathrm{m}$ thick. Note that the concentration of $\mathrm{O}$ in the $\mathrm{Ni}_{3} \mathrm{Al}$ coatings throughout its thickness is only about 7-12 at.\%, which is well below the expected stoichiometric concentration for $\mathrm{NiO}$ and $\mathrm{Al}_{2} \mathrm{O}_{3}$. Such a low concentration of $\mathrm{O}$ suggests that $\mathrm{Ni}_{3} \mathrm{Al}$ coatings are only slightly oxidised even at $3000 \mathrm{~h}$. Nonetheless, it has been suggested that the formation of $\mathrm{NiO}_{\mathrm{x}}$ and $\mathrm{AlO}_{\mathrm{x}}$ prohibits further diffusion of $\mathrm{O}$ and $\mathrm{Na}$, even at sub-stoichiometric $[38,61]$. The extremely low concentration of $\mathrm{O}$ of $<3$ at.\% in the SS347 substrate at $3000 \mathrm{~h}$ also suggests that the substrates remain metallic and free from oxidation. A further improvement in oxidation resistance of $\mathrm{Ni}_{3} \mathrm{Al}$ coatings can be potentially achieved by minimising the quantity of unmelted $\mathrm{AlO}_{\mathrm{x}}$ particles introduced during deposition. It is also important to mention that a small amount of $\mathrm{FeAlO}_{\mathrm{x}}$ is found on the surface of $\mathrm{Ni}_{3} \mathrm{Al}$ coatings, and further investigation in future studies is required to elucidate the origin of these oxide compounds.

In contrast to $\mathrm{Ni}_{3} \mathrm{Al} / \mathrm{SS} 347$, the bare SS347 exhibits a formation of stratified corrosion layers with various $\mathrm{O}$ and $\mathrm{Na}$ concentrations that reach a total thickness of $30-45 \mu \mathrm{m}$ at $3000 \mathrm{~h}$ in molten salts. These corrosion layers are observed to continuously grow in thickness with the increase in molten nitrate salt immersion time at a growth rate of $\sim 87.6 \mu \mathrm{m} /$ year (see Supporting Information Fig. S3a-e and S4) [22]. The qualitative cross-sectional EDS maps suggests a rapid uptake of $\mathrm{O}$ and $\mathrm{Na}$ from the molten salt along with an outward migration of $\mathrm{Fe}$, Ni and $\mathrm{Cr}$ from the SS347 (Fig. 4a). The uptake of $\mathrm{O}$ and $\mathrm{Na}$ by SS347 at an elevated temperature leads to the formation of $\mathrm{FeO}_{\mathrm{x}}$ and $\mathrm{NaFeO}_{\mathrm{x}}$ on the outer layers, both are known to form on the surface of stainless steel substrates after molten salt immersion [31, 32, 50]. The fact that $\mathrm{O}$ is found much deeper in the substrate than $\mathrm{Na}$, which

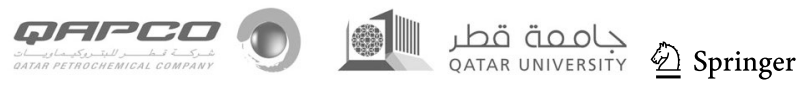


Fig. 3 (a) Elemental maps and corresponding SEM image of cross-sectioned $\mathrm{Ni}_{3} \mathrm{Al} / \mathrm{SS} 347$ at $3000 \mathrm{~h}$ in molten nitrate salt at $565^{\circ} \mathrm{C}$. These maps show spatial distribution of $\mathrm{Fe}, \mathrm{Ni}, \mathrm{Al}, \mathrm{O}$ and $\mathrm{Na}$ at the interface between $\mathrm{Ni}_{3} \mathrm{Al}$ coating and $\mathrm{SS} 347$ substrate. Arrows indicate $\mathrm{AlO}_{\mathrm{x}}$ particles embedded within the $\mathrm{Ni}_{3} \mathrm{Al}$ coatings. All scale bars represent $50 \mu \mathrm{m}$. (b) Elemental composition in atomic percentage (at. \%) of $\mathrm{Fe}, \mathrm{Ni}, \mathrm{Al}, \mathrm{O}$ and $\mathrm{Na}$ of $\mathrm{Ni}_{3} \mathrm{Al} / \mathrm{SS} 347$ taken at the area indicated by white line in the corresponding SEM image. The composition is obtained at $3000 \mathrm{~h}$ and presented as a function of the distance from the interface between $\mathrm{Ni}_{3} \mathrm{Al}$ coating and SS347 substrate. Positive distance corresponds to coatings (Coat) and outer mounting resin (Out), while negative distance corresponds to substrate (Sub). Solid lines are $\sim 5-\mu \mathrm{m}$ simple moving average to guide the eye. (a)
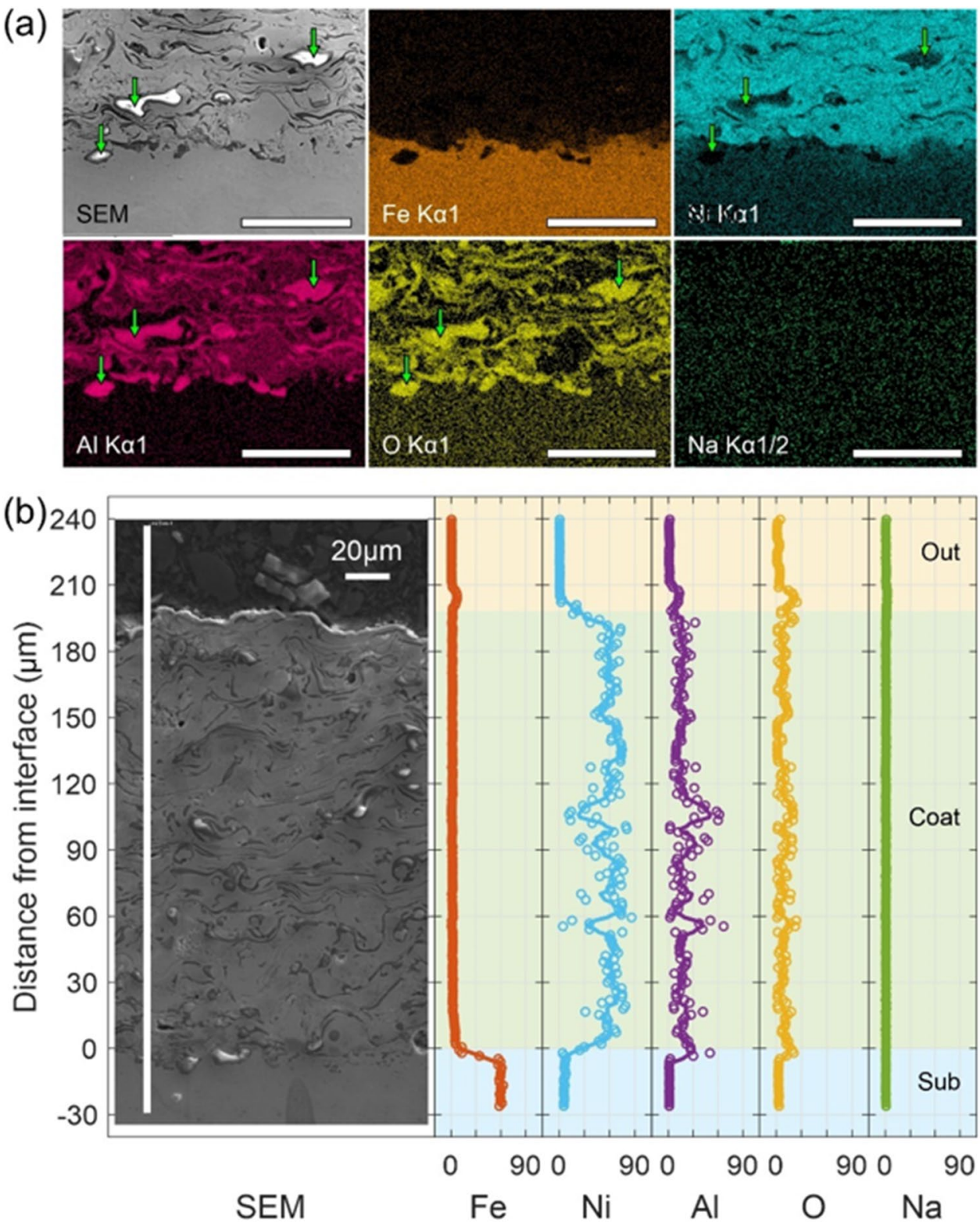

is found only on the surface, suggests that the absorption kinetic of $\mathrm{O}$ is much higher than that of $\mathrm{Na}$. This finding is indeed expected as $\mathrm{O}^{2-}$ anions readily react with cationic $\mathrm{Fe}$ to form a relatively stable $\mathrm{FeO}_{\mathrm{x}}$ despite the ionic radius of $\mathrm{O}^{2-}$ at $\sim 0.14 \mathrm{~nm}$ is larger than that of $\mathrm{Na}^{+}$at $\sim 0.102 \mathrm{~nm}$ $[51,52]$. The intercalation of $\mathrm{Na}^{+}$cations is known to be sluggish and highly dependent on the crystalline structure of the formed $\mathrm{FeO}_{\mathrm{x}}$ [53]. The outward migration of $\mathrm{Fe}, \mathrm{Ni}$ and $\mathrm{Cr}$ can be observed in the inner part of these corrosion layers. Such a migration is also expected as $\mathrm{Cr}$ is known to be highly soluble in molten nitrate salts [54].

A quantitative elemental composition analysis of crosssectioned SS347 at $3000 \mathrm{~h}$ suggests that the outermost layer formed immediately under the salt deposit is a combination of $\mathrm{NaFeO}_{\mathrm{x}}$ and $\mathrm{FeO}_{\mathrm{x}}$ with O:Fe at.\% ratio of $4: 5$ and a relatively high $\mathrm{Na}$ content of 3-9 at.\% (Fig. 4b). The subsequent $\mathrm{FeO}_{\mathrm{x}}$ layer is also found to be Fe-rich with O:Fe at.\% ratio of 3:5, but with a negligible amount of $\mathrm{Na}$. The inner $\mathrm{FeO}_{\mathrm{x}}$ layer is found to have an equal amount of $\mathrm{O}$ and $\mathrm{Fe}$ and contains a significant amount of $\mathrm{Ni}$ and $\mathrm{Cr}$ with a concentration range of 8-18 at.\% and $23-38$ at.\%, respectively. It is important to note that the concentration of $\mathrm{Ni}$ and $\mathrm{Cr}$ in this layer, each at $\sim 5$ at.\% and 22 at.\%, respectively, is higher than that in the substrate. Furthermore, the Fe content in the inner layer is found to be considerably low at $\sim 21$ at.\%, which is less than half of that in the outer layers. This observation is in agreement with previous studies where the inward diffusion of $\mathrm{O}$ strongly correlates with the growth of $\mathrm{Cr}$ and $\mathrm{Ni}$ enrichment zone through formation of precipitates and the depletion of Fe through outward migration

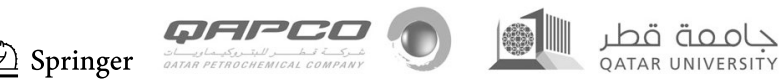


Fig. 4 (a) Elemental maps and corresponding SEM image of cross-sectioned SS347 at $3000 \mathrm{~h}$ in molten nitrate salt at $565^{\circ} \mathrm{C}$. These maps show spatial distribution of $\mathrm{Fe}, \mathrm{Ni}$, $\mathrm{Cr}, \mathrm{O}$ and $\mathrm{Na}$ at the surface of SS347 substrate. All scale bars represent $50 \mu \mathrm{m}$. (b) Elemental composition in atomic percentage (at.\%) of $\mathrm{Fe}, \mathrm{Ni}, \mathrm{Cr}, \mathrm{O}$ and $\mathrm{Na}$ of SS347 taken at the area indicated by white line in the corresponding SEM image. The composition is obtained at $3000 \mathrm{~h}$ and presented as a function of the distance from the interface between corrosion layers and SS347 substrate. Positive distance corresponds to corrosion layers (Cor) and outer mounting resin (Out), while negative distance corresponds to substrate (Sub). Solid lines are $\sim 5$ - $\mu \mathrm{m}$ simple moving average to guide the eye. (a)
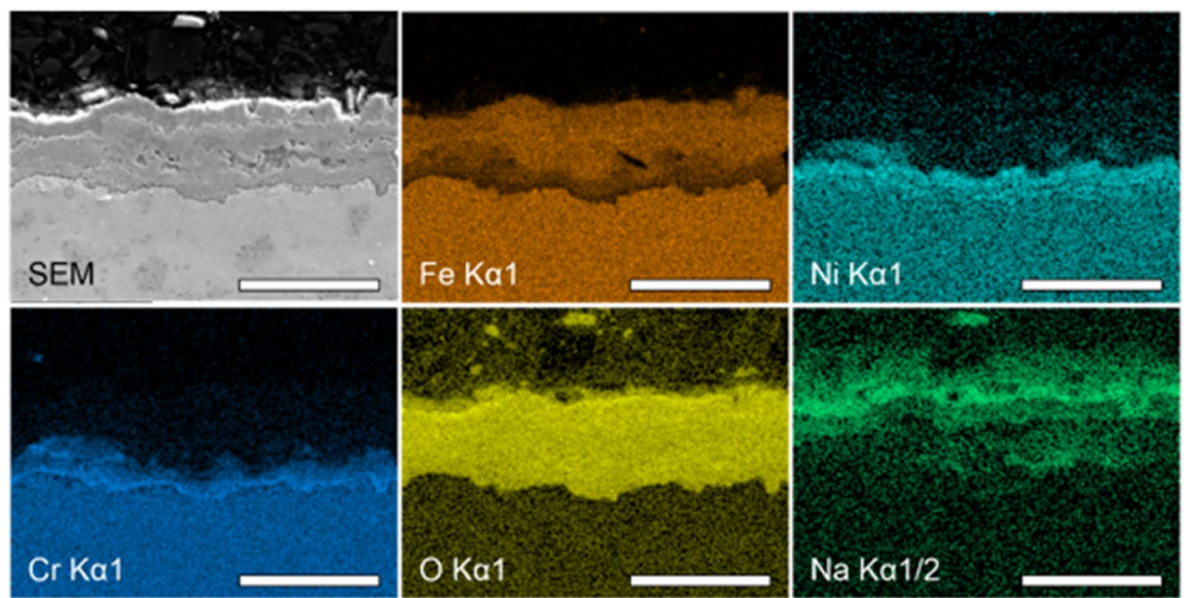

(b) 60

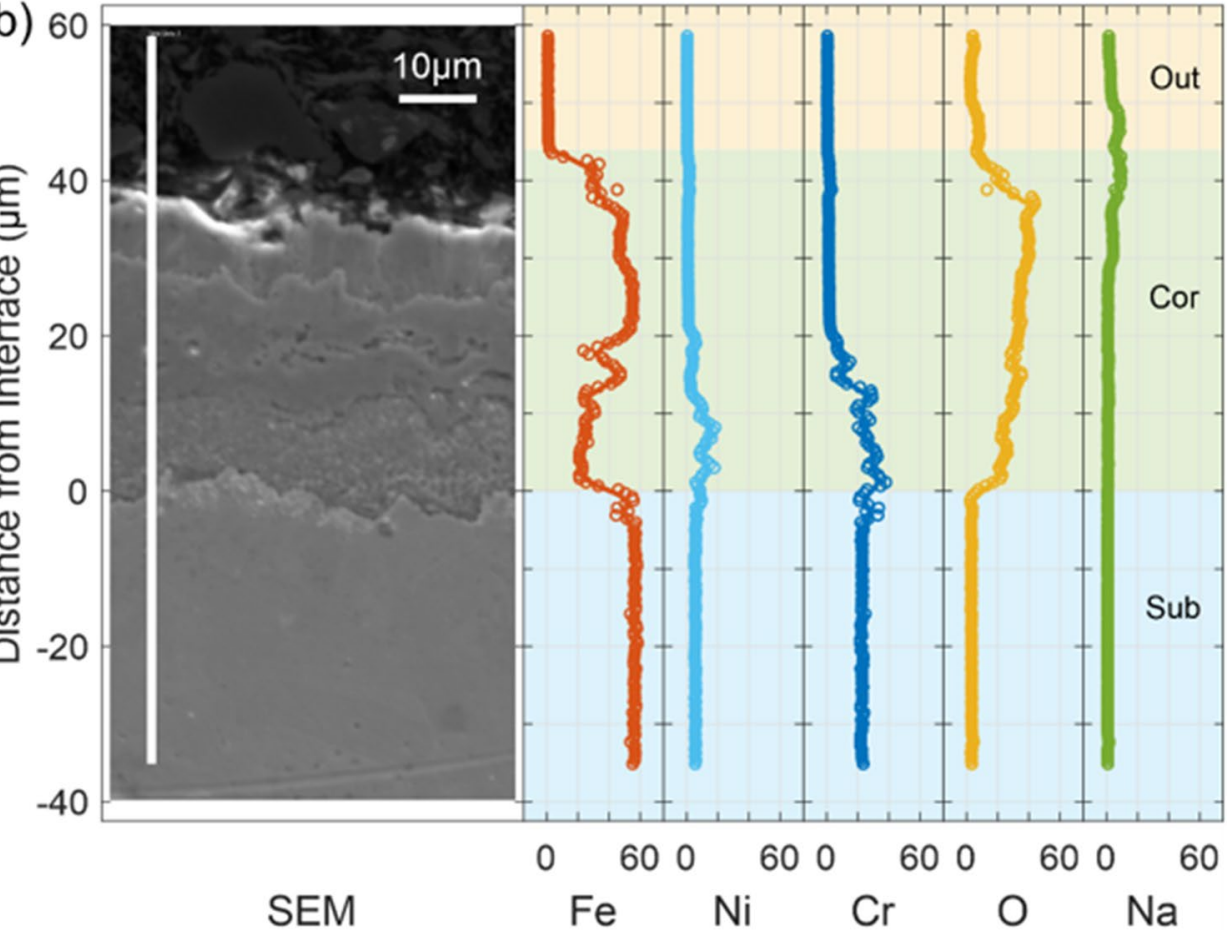

toward the molten salts $[42,43,55]$. These inward diffusion of $\mathrm{O}$ and outward migration of $\mathrm{Fe}$ are the main reason for the discrepancy between the growth rate of corrosion layers observed by SEM (Fig. 2d) and the calculated corrosion rate based on gravimetric analysis (Fig. 1b; Supporting Information Table S2). Note that, as discussed above, the corrosion layers' growth rate is about two orders of magnitude higher than the gravimetrically calculated corrosion rate. The formation of $\mathrm{NaFeO}_{\mathrm{x}}$ and $\mathrm{FeO}_{\mathrm{x}}$ renders the use of constant density for corrosion rate calculation incorrect, as both have much lower densities than that of the SS347 substrate. In addition, the depletion of Fe from the substrate may counterbalance the uptake of $\mathrm{O}$ from the molten salts in terms of mass and thus supresses the apparent $\Delta \mathrm{M} / \mathrm{A}$. Despite this discrepancy, the gravimetric analysis captures the general growth behaviour of the corrosion layers. Further investigation in future studies is required to elucidate the exact correlation between them so one can estimate the growth rate of the corrosion layers simply by gravimetrically calculated corrosion rate.

The presence of $\mathrm{NaFeO}_{\mathrm{x}}$ and $\mathrm{FeO}_{\mathrm{x}}$ on $\mathrm{SS} 347$ and their absence on $\mathrm{Ni}_{3} \mathrm{Al} / \mathrm{SS} 347$ can be further observed from their respective XRD patterns (Fig. 5a). For SS347 in molten salts, the prominent diffraction peaks observed at $1000 \mathrm{~h}$ are attributed to $\mathrm{Fe}_{3} \mathrm{O}_{4}$ and $(\mathrm{Cr}, \mathrm{Fe})_{2} \mathrm{O}_{3}$. The fact that these peaks are much more prominent than those for $\mathrm{CrFeNi}$, which are typical for austenitic stainless steel, suggests that the formation of $\mathrm{Cr}$ and $\mathrm{Ni}$ enrichment zone takes place within the first $1000 \mathrm{~h}$. The disappearance of diffraction peaks for $\mathrm{CrFeNi}$ at $2000 \mathrm{~h}$ supports our previous observation that the

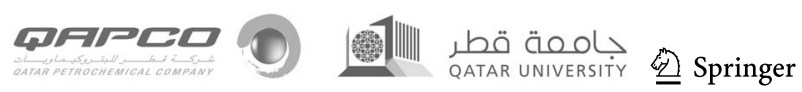


Fig. 5 (a) XRD patterns of $\mathrm{Ni}_{3} \mathrm{Al} / \mathrm{SS} 347$ and SS347 at different molten salt exposure times: 0, 1000, 2000 and 3000 h. SS347 exhibits peaks that correspond to austenitic stainless steel (filled circle) and various oxides of $\mathrm{Fe}$, including $\mathrm{Fe}_{3} \mathrm{O}_{4}$ and $(\mathrm{Cr}, \mathrm{Fe})_{2} \mathrm{O}_{3}$ (filled triangle), $\mathrm{Fe}_{2} \mathrm{NiO}_{4}$ (filled star) and $\mathrm{NaFe}_{2} \mathrm{O}_{3}$ (filled $\mathrm{x}$ mark). $\mathrm{Ni}_{3} \mathrm{Al} / \mathrm{SS} 347$ exhibits peaks that corresponds to $\mathrm{Ni}_{3} \mathrm{Al}$ (filled diamond) and $\mathrm{NiO}$ (filled inverted triangle). Peaks are identified according to the International Centre for Diffraction Data (ICDD) database [31, 33, 56-61] (b) Schematic of corrosion suppression of $\mathrm{Ni}_{3} \mathrm{Al}$ coatings to the SS347 substrate in molten salts. $\mathrm{Ni}_{3} \mathrm{Al}$ coatings are rapidly oxidised and stabilised in the first $500 \mathrm{~h}$. The formation of oxides within the $\mathrm{Ni}_{3} \mathrm{Al}$ coatings supresses the diffusion of $\mathrm{Na}$ from the molten salt or the release of $\mathrm{Fe}, \mathrm{Ni}$ and $\mathrm{Cr}$ from the substrate for at least 3000 h. In contrast, continuous uptake of $\mathrm{O}$ and $\mathrm{Na}$ along with the release of $\mathrm{Fe}, \mathrm{Ni}$ and $\mathrm{Cr}$ resulting in the formation of corrosion layers comprised various oxides of iron on the surface of SS347

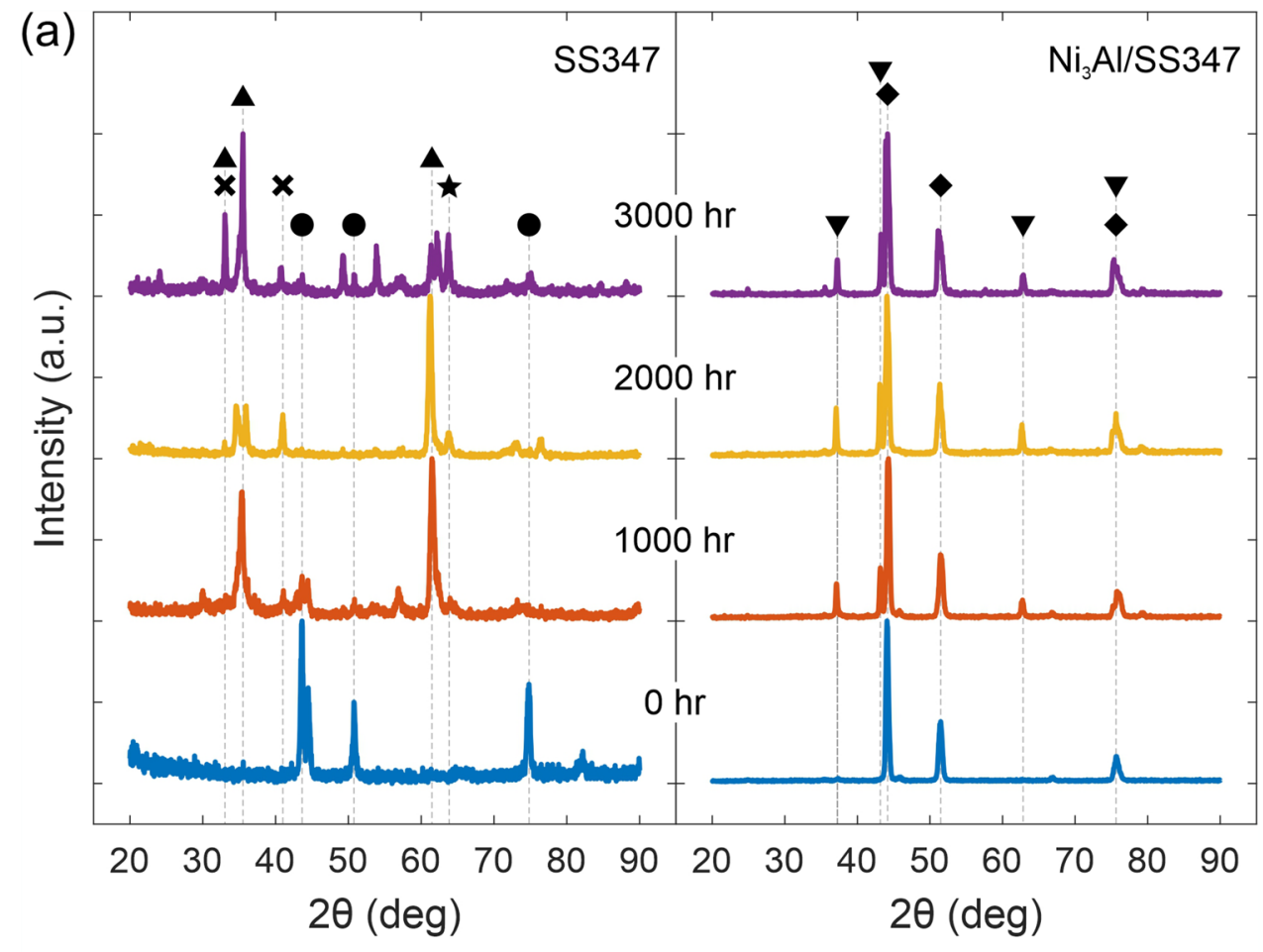

(b)
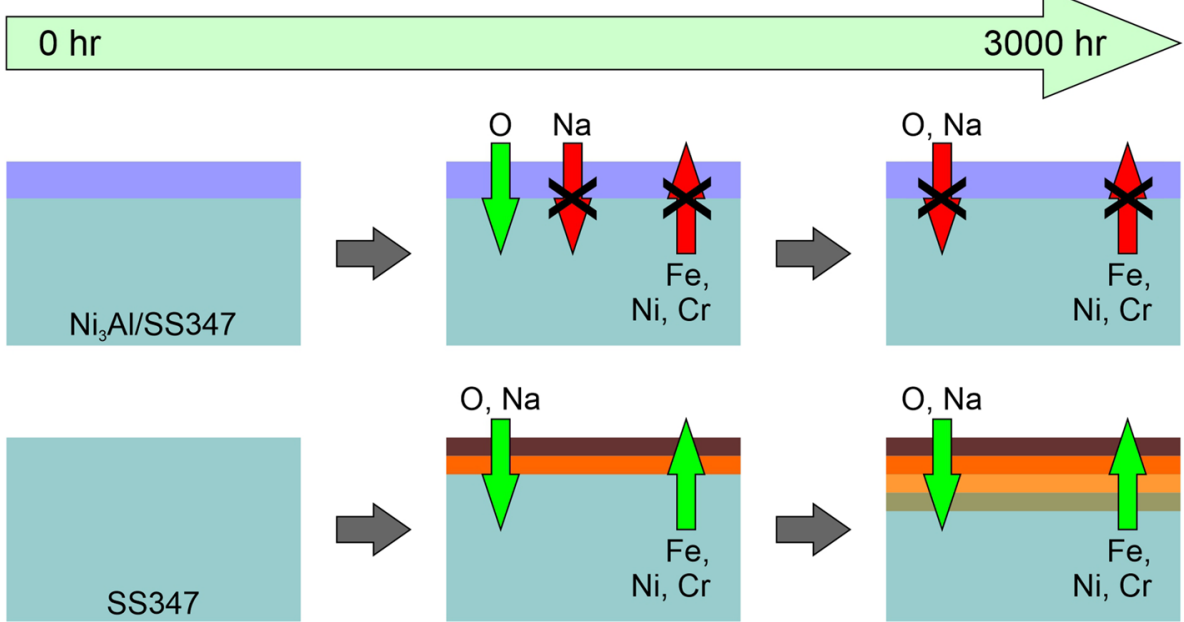

growth of $\mathrm{Cr}$ and $\mathrm{Ni}$ enrichment zone occurs concurrently with depletion of Fe and leads to the formation of $\mathrm{NaFe}_{2} \mathrm{O}_{3}$ and $\mathrm{Fe}_{2} \mathrm{NiO}_{4}$ on the surface. At $3000 \mathrm{~h}$, the XRD pattern of SS347 is fully dominated by peaks attributed to various oxides of Fe including $\mathrm{Fe}_{3} \mathrm{O}_{4}$ and $(\mathrm{Cr}, \mathrm{Fe})_{2} \mathrm{O}_{3}, \mathrm{Fe}_{2} \mathrm{NiO}_{4}$ and $\mathrm{NaFe}_{2} \mathrm{O}_{3}$.

In contrast, the XRD patterns of $\mathrm{Ni}_{3} \mathrm{Al} / \mathrm{SS} 347$ are relatively constant for up to $3000 \mathrm{~h}$ in molten salts where the main distinguishable diffraction peaks are attributed to $\mathrm{Ni}_{3} \mathrm{Al}$ [33, 62-64]. Rapid oxidation of the $\mathrm{Ni}_{3} \mathrm{Al}$ coatings can be observed from the appearance of diffraction peaks attributed to $\mathrm{NiO}$ at $1000 \mathrm{~h}$. Note that no peaks can be attributed to any $\mathrm{Al}_{2} \mathrm{O}_{3}$ phases. This suggests that the formation of $\mathrm{AlO}_{\mathrm{x}}$ observed in qualitative and quantitative elemental analysis is most likely in the amorphous form. It has been suggested that the formation of $\mathrm{AlO}_{\mathrm{x}}$ and $\mathrm{NiO}_{\mathrm{x}}$ inhibits diffusion of $\mathrm{Na}$ and further diffusion of $\mathrm{O}$, especially if a stoichiometric oxide has been formed [38, 48]. Contrary to $\mathrm{CrO}_{\mathrm{x}}$ that is soluble in molten nitrate salts, $\mathrm{AlO}_{\mathrm{x}}$ and $\mathrm{NiO}_{\mathrm{x}}$ are stable and dense enough to create a diffusion barrier [54]. The fact that no peaks can be attributed to $\mathrm{NaFeO}_{\mathrm{x}}$ or $\mathrm{FeO}_{\mathrm{x}}$ implies that the $\mathrm{AlO}_{\mathrm{x}}$ and $\mathrm{NiO}_{\mathrm{x}}$ prevent any uptake of $\mathrm{Na}$ from the salts and acts as an effective diffusion barrier for $\mathrm{Fe}, \mathrm{Ni}$ and $\mathrm{Cr}$. The absence of any observable changes in XRD patterns from $1000 \mathrm{~h}$ onward agrees with our gravimetric analysis and strongly suggests that the $\mathrm{Ni}_{3} \mathrm{Al}$ coatings are stable for at least $3000 \mathrm{~h}$. 


\subsection{Conclusion}

In conclusion, $\mathrm{Ni}_{3} \mathrm{Al}$ coatings provide corrosion resistance to SS347 in the presence of molten $\mathrm{NaNO}_{3}: \mathrm{KNO}_{3}$ salt at $565{ }^{\circ} \mathrm{C}$ for at least $3000 \mathrm{~h} . \mathrm{Ni}_{3} \mathrm{Al}$ coatings undergo a fast oxidation within the first $500 \mathrm{~h}$ of molten salt immersion with a gravimetric rate of $\sim 2 \times 10^{-4} \mathrm{mg} / \mathrm{cm}^{2} / \mathrm{h}$ and then stabilise at a much lower rate of $\sim 1.8 \times 10^{-6} \mathrm{mg} / \mathrm{cm}^{2} / \mathrm{h}$. While this gravimetric rate is only an order of magnitude lower than that for bare SS347 of $3 \times 10^{-5} \mathrm{mg} / \mathrm{cm}^{2} / \mathrm{h}$, the effect of $\mathrm{Ni}_{3} \mathrm{Al}$ coatings on microstructure and elemental composition of SS347 substrates are considerably large. $\mathrm{Ni}_{3} \mathrm{Al}$ coatings inhibit diffusion of $\mathrm{Na}$ and further uptake of $\mathrm{O}$ from the molten salts and supress outward diffusion of Fe, $\mathrm{Cr}$ or Ni from the SS347 substrate (Fig. 5b). On the other hand, multi-layered corrosion products consisting of various oxides of Fe including $\mathrm{FeO}_{x}, \mathrm{NaFeO}_{x}, \mathrm{FeNiO}_{\mathrm{x}}$ and $\mathrm{CrFeO}_{x}$ are readily formed on the surface of SS347. These oxide layers grow continuously in the presence of molten salts and reach a total thickness of $40-45 \mu \mathrm{m}$ within $3000 \mathrm{~h}$. The results presented herein strongly suggest that the $\mathrm{Ni}_{3} \mathrm{Al}$ coatings are protective, by either delaying or stopping altogether the formation of corrosion layers, for use on stainless steel substrates. This enables the potential use of $\mathrm{Ni}_{3} \mathrm{Al}$ coatings as protective coatings to prolong the lifetime of components with long-term isothermal exposure to molten salt, such as the hot TES tanks and piping systems. Further investigation should be undertaken beyond $3000 \mathrm{~h}$ to elucidate the long-term corrosion behaviour of $\mathrm{Ni}_{3} \mathrm{Al}$ coatings and to correlate any morphological and compositional changes to the gravimetric analysis. These are keys to confirm the potential of $\mathrm{Ni}_{3} \mathrm{Al}$ coatings for use in next generation CSP-TES applications. Nonetheless, the approach in this study can be extended for investigation of other corrosion suppression solutions against molten salts to further advance the CSP-TES technology.

Supplementary Information The online version contains supplementary material available at https://doi.org/10.1007/s42247-021-00334-y.

Author contribution Sarah Yasir: Methodology, investigation, visualization, writing - original draft, data curation, formal analysis.

Jose Luis Endrino: Supervision, writing — review and editing.

Elena Guillen: Conceptualization, writing — review and editing.

Adrianus Indrat Aria: Methodology, conceptualization, validation, visualization, supervision, formal analysis, writing - review and editing.

Funding Funding for this work came from the European Union's Horizon 2020 research and innovation programme under the Marie Skłodowska-Curie grant number 645725 (Framework of Innovation for Engineering of New Durable Solar Surfaces - FRIENDS ${ }^{2}$ ) project. SY received studentship from Centre for Doctoral Training in Sustainable Materials and Manufacturing with funding from the Engineering and Physical Research Council grant number EP/L016389/1.
Data Availability Data underlying this study can be accessed through the Cranfield University repository at https://doi.org/10.17862/cranf ield.rd.17269424.

\section{Declarations}

Conflict of interest The authors declare that they have no known competing financial interests or personal relationships that could have appeared to influence the work reported in this paper.

Open Access This article is licensed under a Creative Commons Attribution 4.0 International License, which permits use, sharing, adaptation, distribution and reproduction in any medium or format, as long as you give appropriate credit to the original author(s) and the source, provide a link to the Creative Commons licence, and indicate if changes were made. The images or other third party material in this article are included in the article's Creative Commons licence, unless indicated otherwise in a credit line to the material. If material is not included in the article's Creative Commons licence and your intended use is not permitted by statutory regulation or exceeds the permitted use, you will need to obtain permission directly from the copyright holder. To view a copy of this licence, visit http://creativecommons.org/licenses/by/4.0/.

\section{References}

1. A.G. Fernández, B. Muñoz-Sánchez, J. Nieto-Maestre, A. GarcíaRomero, High temperature corrosion behavior on molten nitrate salt-based nanofluids for CSP plants. Renew Energy 130, 902-909 (2019). https://doi.org/10.1016/j.renene.2018.07.018

2. Grogan, D. Development of molten-salt heat transfer fluid technology for parabolic trough solar power plants. Abengoa. Sol. Sunshot. Conf .Proj. Rev.

3. Siegel, N. P., Bradshaw, R. W., Cordaro AM Kruizenga, J. B. Thermophysical property measurement of nitrate salt heat transfer fluids. Proceedings of the ASME 2011 5th International Conference on Energy Sustainability, 1-8 (2011).

4. G. McConohy, A. Kruizenga, Molten nitrate salts at 600 and $680^{\circ} \mathrm{C}$ : thermophysical property changes and corrosion of hightemperature nickel alloys. Sol. Energy. 103, 242-252 (2014). https://doi.org/10.1016/j.solener.2014.01.028

5. M. Liu, N.H. Steven Tay, S. Bell, M. Belusko, R. Jacob, G. Will, W. Saman, F. Bruno, Review on concentrating solar power plants and new developments in high temperature thermal energy storage technologies. Renew. Sustain. Energy. Rev. 53, 1411-1432 (2016)https://doi.org/10.1016/j.rser.2015.09.026

6. Kuravi, S. Goswami, D.Y., Stefanakos, E.K., Ram, M., Jotshi, C., Trahan, J., Sridharan, P., Rahman, M., Krakow, B. Thermal energy storage for concentrating solar power plants, Clean Energy Research Center, University South Florida. (n.d.)

7. D. Kearney, B. Kelly, U. Herrmann, R. Cable, J. Pacheco, R. Mahoney, H. Price, D. Blake, P. Nava, N. Potrovitza, Engineering aspects of a molten salt heat transfer fluid in a trough solar field. Energy 29, 861-870 (2004). https://doi.org/10.1016/S03605442(03)00191-9

8. S. Kuravi, Y. Goswami, E.K. Stefanakos, M. Ram, C. Jotshi, S. Pendyala, J. Trahan, P. Sridharan, M. Rahman, B. Krakow, Thermal energy storage technologies and systems for concentrating solar power plants. Technol. Innov. 14, 81-91 (2013). https://doi. org/10.3727/194982412X13462021397570

9. J. Gasia, L. Miró, L.F, Cabeza, Review on system and materials requirements for high temperature thermal energy storage. 
Part 1: general requirements. Renew. Sustain. Energy. Rev. 75, 1320-1338 (2017)

10. R.I. Olivares, The thermal stability of molten nitrite/nitrates salt for solar thermal energy storage in different atmospheres. Sol. Energy. 86, 2576-2583 (2012). https://doi.org/10.1016/j.solener. 2012.05.025

11. H. Benoit, L. Spreafico, D. Gauthier, G. Flamant, Review of heat transfer fluids in tube-receivers used in concentrating solar thermal systems: properties and heat transfer coefficients. Renew. Sustain. Energy. Rev. 55, 298-315 (2016). https://doi.org/10.1016/j. rser.2015.10.059

12. R.I. Dunn, P.J. Hearps, M.N. Wright, Molten-salt power towers: newly commercial concentrating solar storage. Proc. IEEE. 100, 504-515 (2012). https://doi.org/10.1109/JPROC.2011.2163739

13. A.B. Zavoico, Solar power tower - design basis document. Tech. Rep. SAND2001-2100, 148 (2001). https://doi.org/10.2172/ 786629

14. V. Encinas-Sánchez, E. Batuecas, A. Macías-García, C. Mayo, R. Díaz, F.J. Pérez, Corrosion resistance of protective coatings against molten nitrate salts for thermal energy storage and their environmental impact in CSP technology. Solar. Energy. 176, 688-697 (2018). https://doi.org/10.1016/j.solener.2018.10.083

15. Tortorelli, P.F., Bishop, P.S., DiStefano, J.R. Selection of corrosion-resistant materials for use in molten nitrate salts.(1989)

16 A. SoleimaniDorcheh, M.C. Galetz, Slurry aluminizing: a solution for molten nitrate salt corrosion in concentrated solar power plants. Sol. Energy. Mater. Solar. Cells. 146, 8-15 (2016). https:// doi.org/10.1016/j.solmat.2015.11.024

17. J.W. Slusser, J.B. Titcomb, M.T. Heffelfinger, B.R. Dunbobbin, Corrosion in molten nitrate-nitrite salts. Jom. 37, 24-27 (1985). https://doi.org/10.1007/BF03259692

18. S.H. Goods, R.W. Bradshaw, Corrosion of stainless steels and carbon steel by molten mixtures of commercial nitrate salts. J. Mater. Eng. Perform. 13, 78-87 (2004). https://doi.org/10.1361/ 10599490417542

19. a. G. Fernández, M.I. Lasanta, F.J. Pérez, Molten salt corrosion of stainless steels and low-Cr steel in CSP plants. Oxid. Met. 78, 329-348 (2012). https://doi.org/10.1007/s11085-012-9310-x

20. Bradshaw, R.W., Goods, S.H. Corrosion resistance of stainless steels during thermal cycling in alkali nitrate. Sandia. Rep. 1-39 (2001)

21. Kruizenga, A.M., Gill, D.D., Laford, M., Mcconohy, G. Corrosion of high temperature alloys in solar salt at 400,500 , and $680^{\circ} \mathrm{C}$. Sandia. Rep. 1-45 (2013)

22. M. Gurr, S. Bau, F. Burmeister, M. Wirth, E. Piedra-Gonzalez, K. Krebser, J. Preußner, W. Pfeiffer, Investigation of the corrosion behavior of NiVAl multilayer coatings in hot salt melts. Surf. Coatings. Technol. 279, 101-111 (2015). https://doi.org/10. 1016/j.surfcoat.2015.07.045

23. R. Moore, M. Vernon, C.K. Ho, N.P. Siegel, G.J. Kolb, S.N. Laboratories, P.O.B. Albuquerque, Design considerations for concentrating solar power tower systems employing molten salt. Security 2010, 1-51 (2010). https://doi.org/10.2172/1008140

24. M. Spiegel, J. Mentz, High temperature corrosion beneath nitrate melts. Mater. Corros. 65, 276-281 (2014). https://doi.org/10.1002/ maco. 201307076

25. P. Audigié, V. Encinas-Sánchez, M. Juez-Lorenzo, S. Rodríguez, M. Gutiérrez, F.J. Pérez, A. Agüero, High temperature molten salt corrosion behavior of aluminide and nickel-aluminide coatings for heat storage in concentrated solar power plants. Surf. Coatings. Technol. 349, 1148-1157 (2018). https://doi.org/10.1016/j.surfc oat.2018.05.081

26. H. Singh, B.S. Sidhu, D. Puri, S. Prakash, Use of plasma spray technology for deposition of high temperature oxidation/corrosion resistant coatings - a review. Mater. Corros. 58, 92-102 (2007). https://doi.org/10.1002/maco.200603985
27. N. Cinca, J.M. Guilemany, Thermal spraying of transition metal aluminides: an overview. Intermetallics 24, 60-72 (2012). https:// doi.org/10.1016/j.intermet.2012.01.020

28. H. Singh, D. Puri, S. Prakash, Some studies on hot corrosion performance of plasma sprayed coatings on a Fe-based superalloy. Surf. Coatings. Technol. 192, 27-38 (2005). https://doi.org/10. 1016/j.surfcoat.2004.03.030

29 S. Kumar, V. Selvarajan, P.V.A.V.A. Padmanabhan, K.P.P. Sreekumar, Characterization and comparison between APS coatings prepared from ball milled and plasma processed nickel-aluminium powders. Mater. Sci. Eng. A. 486, 287-294 (2008). https://doi.org/ 10.1016/j.msea.2007.09.003

30. M.C. Trent, S.H. Goods, R.W. Bradshaw, Comparison of corrosion performance of grade 316 and grade $347 \mathrm{H}$ stainless steels in molten nitrate salt. Conf. Proc. (2016). https://doi.org/10.1063/1. 4949258

31. A. Kruizenga, D. Gill, Corrosion of iron stainless steels in molten nitrate salt. Energy. Proc. 49, 878-887 (2013). https://doi.org/10. 1016/j.egypro.2014.03.095

32. Bradshaw, R.W., Goods, S.H. Corrosion of alloys and metals by molten nitrates. (2001)

33. S.B.B. Mishra, K. Chandra, S. Prakash, B. Venkataraman, Characterisation and erosion behaviour of a plasma sprayed Ni3Al coating on a Fe-based superalloy. Mater. Lett. 59, 3694-3698 (2005). https://doi.org/10.1016/j.matlet.2005.06.050

34. B.S. Sidhu, S. Prakash, Degradation behavior of Ni3Al plasmasprayed boiler tube steels in an energy generation system. J. Mater. Eng. Perform. 14, 356-362 (2005). https://doi.org/10.1361/10599 490523382

35 J.T. Chang, a. Davison, J.L. He, a. Matthews, Deposition of Ni$\mathrm{Al}-\mathrm{Y}$ alloy films using a hybrid arc ion plating and magnetron sputtering system. Surf. Coatings. Technol. 200, 5877-5883 (2006). https://doi.org/10.1016/j.surfcoat.2005.08.138

36 S.C. Mishra, a. Satapathy, M. Chaithanya, P.V. Ananthapadmanabhan, K.P. Sreekumar, Wear Characteristics of plasma sprayed nickel-aluminum composite coatings. J. Reinf. Plast. Compos. 28, 2931-2940 (2009). https://doi.org/10.1177/0731684408094067

37. B.S. Sidhu, S. Prakash, Evaluation of the corrosion behaviour of plasma-sprayed $\mathrm{Ni} 3 \mathrm{Al}$ coatings on steel in oxidation and molten salt environments at 9008 C. Surf. Coatings Technol. 166, 89-100 (2003). https://doi.org/10.1016/S0257-8972(02)00772-7

38. S.B. Mishra, K. Chandra, S. Prakash, Studies on erosion-corrosion behaviour of plasma sprayed $\mathrm{Ni} 3 \mathrm{Al}$ coating in a coalfired thermal power plant environment at $540^{\circ} \mathrm{C}$. Anti. Corros. Methods. Mater. 64, 540-549 (2017). https://doi.org/10.1108/ ACMM-11-2015-1592

39. Jonemann, M. Advanced Thermal Storage System with Novel Molten Salt. (2013)

40. M. Walczak, F. Pineda, Á.G. Fernández, C. Mata-Torres, R.A. Escobar, Materials corrosion for thermal energy storage systems in concentrated solar power plants. Renew. Sustain. Energy. Rev. 86, 22-44 (2018). https://doi.org/10.1016/j.rser.2018.01.010

41. A. Soleimani, R.N. Durham, M.C. Galetz, Corrosion behavior of stainless and low-chromium steels and IN625 in molten nitrate salts at $600^{\circ}$ C. Sol. Energy. Mater. Sol. Cells. 144, 109-116 (2016)

42. A.G. Fernández, H. Galleguillos, E. Fuentealba, F.J. Pérez, Corrosion of stainless steels and low-Cr steel in molten $\mathrm{Ca}(\mathrm{NO} 3) 2-$ NaNO3-KNO3 eutectic salt for direct energy storage in CSP plants. Sol. Energy. Mater. Sol. Cells. 141, 7-13 (2015). https:// doi.org/10.1016/j.solmat.2015.05.004

43. Kruizenga, A.M., Gill, D.D., Laford, M. Materials Corrosion of high temperature alloys immersed in $600^{\circ} \mathrm{C}$ binary nitrate salt. Sandia Rep. (2013) 
44. B. Jm.At.La. T, Influence of alloy microstructure on oxide growth in HCM12A in supercritical water. Mater. Res. Soc. Symp. Proc. Proc. 2009, 19-24 (2009)

45. Y. Li, D.D. Macdonald, J. Yang, J. Qiu, S. Wang, Point defect model for the corrosion of steels in supercritical water: part I, film growth kinetics. Corros. Sci. 163, 108280 (2020). https://doi.org/ 10.1016/j.corsci.2019.108280

46. T.D. Nguyen, J. Zhang, D.J. Young, Water vapour effects on corrosion of $\mathrm{Fe}-\mathrm{Cr}$ and $\mathrm{Fe}-\mathrm{Cr}-\mathrm{Ni}$ alloys containing cerium and manganese in $\mathrm{CO} 2$ gas at $818^{\circ} \mathrm{C}$. Corros. Sci. 89, 220-235 (2014). https://doi.org/10.1016/j.corsci.2014.08.029

47. B. Picqué, P.O. Bouchard, P. Montmitonnet, M. Picard, Mechanical behaviour of iron oxide scale: experimental and numerical study. Wear 260, 231-242 (2006). https://doi.org/10.1016/j.wear. 2005.03.037

48. S. Saladi, J.V. Menghani, S. Prakash, Characterization and evaluation of cyclic hot corrosion resistance of detonation-gun sprayed Ni-5Al coatings on Inconel-718. J Therm. Spray. Technol. 24, 778-788 (2015). https://doi.org/10.1007/s11666-015-0235-1

49 K. Mehmood, M.A. Rafiq, A. Nusair Khan, M.M. Rauf, Microstructural study of as sprayed and heat treated Ni 3 Al coatings deposited by air plasma spraying technique. IOP Conf. Ser. Mat. Sci. Eng. 2016, 146 (2016). https://doi.org/10.1088/1757-899X/ $146 / 1 / 012050$

50. M. Kumar, H. Singh, N. Singh, Study of Ni-20Cr coatings for high temperature applications - a review. Arch. Metallur. Mater. 58, 523-528 (2013). https://doi.org/10.2478/amm-2013-0030

51 R.D. Shannon, Revised effective ionic radii and systematic studies of interatomic distances in halides and chalcogenides. Acta. Cryst. 1976, 751-767 (1976). https://doi.org/10.1107/S05677394760015 51

52 L.H. Ahrens, The use of ionization potentials part 1 Ionic radii of the elements. Geochim. Cosmochim. Acta. 2, 155-169 (1952). https://doi.org/10.1016/0016-7037(52)90004-5

53. Y. Takeda, J. Akagi, A. Edagawa, M. Inagaki, S. Naka, A preparation and polymorphic relations of sodium iron oxide ( $\mathrm{NaFeO} 2)$. Mater. Res. Bull. 15, 1167-1172 (1980). https://doi.org/10.1016/ 0025-5408(80)90081-1

54 G. Fernández, I. Rey, S. Lasanta, M.P. Mato, F..J.. Pérez. Brady, Corrosion of alumina-forming austenitic steel in molten nitrate salts by gravimetric analysis and impedance spectroscopy. Mater. Corros. 65, 267-275 (2014). https://doi.org/10.1002/maco.20130 7422
55 D. Kumar, K. Pandey, Optimization of the process parameters in generic thermal barrier coatings using the Taguchi method and grey relational analysis. Proc. Ins. Mech. Eng. Part. L. J. Mat. Des. Appl. 231, 600-610 (2017). https://doi.org/10.1177/1464420715 602727

56. ICDD. Powder diffraction file -2, Int. Cent. Diffr. Data Database. (n.d.)

57. J.T. Guo, L.Y. Sheng, Y. Xie, Z.X. Zhang, V.E. Ovcharenko, H.Q. Ye, Microstructure and mechanical properties of $\mathrm{Ni} 3 \mathrm{Al}$ and $\mathrm{Ni}$ 3Al-1B alloys fabricated by SHS/HE. Intermetallics 19, 137-142 (2011). https://doi.org/10.1016/j.intermet.2010.08.027

58. E. Liu, J. Jia, Y. Bai, W. Wang, Y. Gao, Study on preparation and mechanical property of nanocrystalline $\mathrm{NiAl}$ intermetallic. Mater. Des. 53, 596-601 (2014). https://doi.org/10.1016/j.matdes.2013. 07.052

59. J. Swaminathan, R. Singh, M.K. Gunjan, B. Mahato, Sensitization induced stress corrosion failure of AISI 347 stainless steel fractionator furnace tubes. Eng. Fail. Anal. 18, 2211-2221 (2011). https://doi.org/10.1016/j.engfailanal.2011.07.015

60. Y. Behnamian, A. Mostafaei, A. Kohandehghan, B.S. Amirkhiz, D. Serate, W. Zheng, D. Guzonas, M. Chmielus, W. Chen, J.L. Luo, Characterization of oxide scales grown on alloy $310 \mathrm{~S}$ stainless steel after long term exposure to supercritical water at $500{ }^{\circ} \mathrm{C}$. Mater. Charact. 120, 273-284 (2016). https://doi.org/10.1016/j. matchar.2016.09.013

61. A.G. Fernández, H. Galleguillos, F.J. Pérez, Thermal influence in corrosion properties of Chilean solar nitrates. Sol. Energy. 109, 125-134 (2014). https://doi.org/10.1016/j.solener.2014.07.027

62. M. Konieczny, Mechanical properties and deformation behavior of laminated $\mathrm{Ni}-(\mathrm{Ni} 2 \mathrm{Al}+\mathrm{NiAl3})$ and $\mathrm{Ni}-(\mathrm{Ni} 3 \mathrm{Al}+\mathrm{NiAl})$ composites. Mater. Sci. Eng. A. 586, 11-18 (2013). https://doi.org/10.1016/j. msea.2013.08.002

63. G.S. Cho, K.R. Lee, K.H. Choe, K.W. Lee, A, Ikenaga (2006) Fabrication of Ni-Al intermetallic compounds on the Al casting alloy by SHS process, Inst Cast Met Eng - 67th World Foundry Congr Wfc06 Cast. Future 1, 361-370 (2006)

64. J. Cao, X.G. Song, L.Z. Wu, J.L. Qi, J.C. Feng, Characterization of $\mathrm{Al} / \mathrm{Ni}$ multilayers and their application in diffusion bonding of TiAl to TiC cermet. Thin Solid Films 520, 3528-3531 (2012). https://doi.org/10.1016/j.tsf.2012.01.001 